\title{
An Analysis of Maritime Security Concept Based on International Safety Management (ISM) Code at The II Class Harbormaster and Port Authority (KSOP) Tanjungpinang
}

\author{
Carry Anggun Simanjuntak ${ }^{1}$, Risandi Dwirama Putra ${ }^{2 *}$, Glory Yolanda Yahya ${ }^{1}$, and Dhani Akbar ${ }^{1}$, Sayed Fauzan \\ Riyadi ${ }^{1}$
}

1International Relations Department, Faculty of Social and Political Sciences, Universitas Maritim Raja Ali Haji, Jl. Raya Dompak Tanjungpinang, Riau Archipelago 29111, Indonesia

2Shipping Engineering Department, Faculty of Engineering, Universitas Maritim Raja Ali Haji, Jl. Raya Senggarang Tanjungpinang, Riau Archipelago 29125, Indonesia

*Coresspondence Author: risandi@umrah.ac.id

\begin{abstract}
The ISM Code's objective is to improve safety and prevent accidents and pollution as regulated by the International Maritime Organization and has been ratified since 1994 by Indonesia and applies to each province, including the Riau Archipelago. The Riau Archipelago almost had $96 \%$ of the marine area as its territory and directly borders Singapore and Malaysia with high sea transportation activities and has a strategic role in international trade traffic. This study aimed to analyze the implementation of the ISM Code at KSOP II Class Tanjungpinang through the concept of maritime security. The research method used was the qualitative method. The data obtained were systematically compiled and analyzed qualitatively using the international regime effectiveness analysis. The concept of maritime security was used to answer the implementation of the ISM Code at II Class KSOP Office Tanjungpinang. The application of the ISM Code at II Class KSOP Office Tanjungpinang had to be considered to ensure safe sea transportation activities as regulated by IMO and legalized in each province of Indonesia. The results of this study were necessary to optimize each maritime actor's function who had legal responsibilities. There were required changes in focus, understanding, and awareness of the importance of maritime security to optimize resources and tasks on an ongoing basis and emphasize preventive and repressive efforts. This assisted in preventing the recurrence of threats and violations of the law in the marine area directly adjacent to the Riau Archipelago.
\end{abstract}

\section{Introduction}

Indonesia, an archipelagic country, borders a large sea area and is also known as one of the owners of Malacca Strait and the South China Sea (the North Natuna Sea), which is in the Riau Archipelago Province (Kepri). Kepri has neighboring countries with direct borders, such as Vietnam, Malaysia, Cambodia, and Singapore, making Kepri strategic in world trade traffic [1], especially its sea routes. Kepri sea area reaches $96 \%$ of its total area [2], sea transportation is one of the tools needed in shipping and delivery. Therefore, sea transportation can reach the islands in Kepri easily and cheaply. Likewise, for the destinations of Singapore and Malaysia, the country borders Tanjungpinang. For this reason, it is necessary to have something that can fulfill the obligations for safety and security operations, through the International Safety Management (ISM) Code's implementation that has been made by the International Maritime Organization (IMO) [3] in the form of Safety Management and Pollution Prevention from ships which is regulated through the provisions of Article 169 of the Law of the Republic of Indonesia Number 17 of 2008 about Shipping [4].

Indonesian Government makes the several divisions of maritime laws through the Law of the Republic of Indonesia, Presidential and Ministerial Regulation that have the responsibility of enforcing 
and supervising the safety of maritime transportation activities, security of facilities where ships dock (on ports), and protect the maritime from dangerous actions [5], [6]. Those responsibilties are fallen under some institution, such as the Harbormaster and Port Authority (KSOP), with the function of implementing, monitoring, and enforcing the seaworthiness, shipping safety, and authority to secure and controling ports as stated in Article 208 of the Law of the Republic of Indonesia Number 17 of 2008 about Shipping.

The Navigation District Office, which also has responsibility for the safety of ship's navigation, participates in coordinating the planning of navigation operations, as well as inspection and supervision of navigational equipment as stated in the Regulation of the Minister of Transportation of the Republic of Indonesia Number PM 78 of 2013 [7]. Indonesia Sea and Coast Guard (KPLP) has the authority to ensure the safety and security of the waters as a safeguard and law enforcement officer by preparing policy formulation materials, supervising navigational equipment, and efforts to prevent pollution as regulated in the Regulation of the Minister of Transportation Number: KM 60 of 2010 About the Organization and Working Procedures of the Ministry of Transportation [8]. The government has also made a regulation that directly regulates ship's safety management in the Minister of Transportation Regulation Number: PM 45 of 2012, ensuring ships following the standards, pollution prevention, and certificates' issues [9]. However, ship or pollution accidents still occur despite a certificate that can guarantee the ship's safety. Therefore, it is necessary to increase the enforcement and supervisions in implementing the ISM Code, especially in the Riau Islands. A review of the theory of Liberalism and the International Regime supports the answer to the problems of shipping safety and security management due to the need for sea transportation in the Riau Islands and its strategic role in both domestic and international trade. Therefore, it is necessary to know the effectiveness of implementing the ISM Code in Tanjungpinang through an international regime and maritime security analysis in implementing the ISM Code at II Class Harbormaster and Port Authority (KSOP) Tanjungpinang.

\section{Method}

This research used the qualitative methodology to collect the descriptive data both in written and spoken words that were observed in the field [10]. Through interviews with informants related to the implementation of ship management, the operations could be carried out so far. The obstacles faced in its execution, as well as on the observation and documentation. Qualitative data analysis systematically compiled the interviews, field notes, documentation, and other materials based on the data obtained [11]. Data analysis was carried out starting from the collection until the research's report was completed [12]. Analysis was carried out in conjunction with data collection to sharpen the focus of the observation and deepen the study of analyzing the data from the data grouping, then interpreting every subaspect's meaning and relation to each other. And then analyzed these characteristics to understand the relationship between each of it.

\subsection{Effectiveness of International Regime}

According to Robert Kohane, regimes are institutions with implicit rules, explicitly agreed upon by their members regarding certain issues in international relations [13]. In other words, international regimes can decide and implement it in international cooperation to solve problems in the system. Challenges faced by the government in implementing major policies require a common solution. However, the success rate in collaboration or implementation can be either as a successful or a failed regime. According to Underdal, the regime's international will be effective if it implements as its function or able to solve the problem. According to Arild Underdal, an effective regime is a dependent variable, while the independent variable is the type of problem, and the problem-solving ability. And there is also an intervening variable, namely the level of collaboration between regime's members, where this variable is the result of independent variables that affect the variable dependent.

International regimes produce three components: output, outcome, and impact to analyze the regime's effectiveness [14], [15].

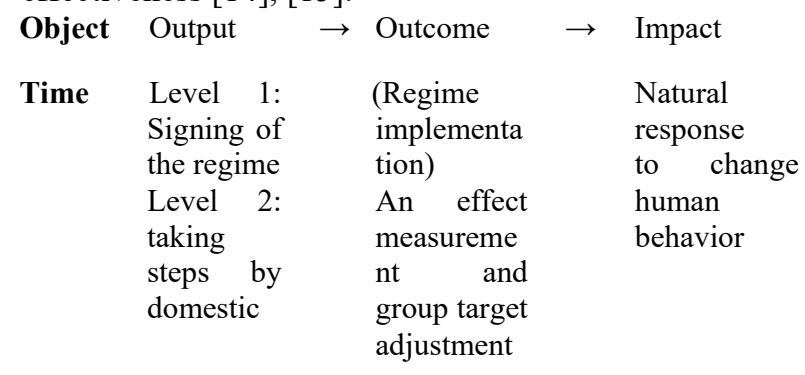

If the relationship between the state tends to be benign, it will make it easier for the regime to achieve its goals or collective agreements. Still, if it is malign, it is unlikely that effective cooperation will be created. The level of the problem is more benign if the choice of actors is identical and harmonious.

Problem's Spite. The spite of the problem or encountered problems can determine the 
effectiveness of a regime. The more complicated the problem, the more there is little chance of effective collaboration. The complexity can be both external and internal (complex factors of the actors in it and the others). By the three characters of problem malignancy, not all countries consider the issue of the regime as a problem and create disagreements (incongruity), differences in national interests between member countries (asymmetry), a split due to differences accumulated (cumulative cleavages).

Problem Solving Capacity. According to Underdal, skill and energy in a good system can solve the problem effectively. First, there are three elements in the problem-solving capacity: institutional setting in the regime, setting the rights and rules in the guide to defining social practice, and making a role in a plan. Second, the distribution of power between actors, dominant and minority parties who bind and encourage each other to realize the regime. The laast, skill and energy play an important role when looking for solutions to overcome regime problems.

Level of collaboration. (0) through ideas, act together without any coordination. (1) coordination of actions secretly. (2) Coordination based on rules or standards, government plays a role as an implementer but does not carry out a centralized assessment will action effectiveness. (3) Coordinate based on rules or standards, the government as full implementer with a centralized assessment of the effectiveness of the action. (4) Planned joint coordination with national-level implementation. Conduct a centralized assessment of the effectiveness of an action. (5) Coordination by planning comprehensive implementation is also integrated with a centralized assessment of effectiveness.

Based on the collaboration level scale, the determination of the level of collaboration on the effectiveness of the regime from the steps of the existence of ideas together, act in coordination, formulate rules explicitly, conduct a centralized assessment of implementation at the national level, planning and execution with integration and coordination planned. See Figure 1. [16] to find out how the regime's effectiveness can be measured through the sustainability of its variables.

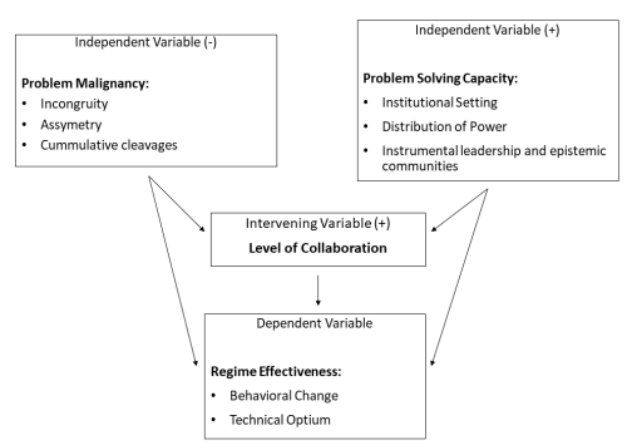

Fig. 1. Effectiveness of a Regime by Arild Underdal.

\subsection{International Safety Management Code (ISM Code)}

According to Keohane, there are two divisions of institutions, namely formal institutions, and informal institutions. Formal institutions are institutions formed by states such as the United Nations (UN) [17]. The organization will supervise activities, respond, including creating a policy on an issue at hand. While informal institutions are a series of agreed regimes or regulations, Keohane defines a regime as a set of rules that control behavior actors where the state uses this regime to deal with issues International Relations. For example, the International Maritime Organization (IMO) is a specialized agency that formed by the United Nations (UN), which has the authority to determine standard ship operators with the responsibility to ensure shipping safety and security and prevention of marine pollution and atmosphere by ships as well as the role of IMO in supporting the SDGs. IMO also has a role in creating a level playing field [18], which is equivalent to avoiding shortcuts and promoting marine safety, security, and environmental performance in shipping companies involved in international trade [19].

IMO is a forum for the effective operation of the process if agrees on rules and standards and implement them. IMO develops and manages the regulatory framework in the shipping industry to be safe, secure, and efficient through several steps that must be considered in aspects such as international shipping, including ship design, construction, equipment, manning an operation, and waste disposal. Then IMO also has a role in ensuring that the sector remains safe, environmentally friendly, and cost-effective energy. IMO was formed through the proposals of several countries that need an international body to promote maritime safety effectively. Playing a role in ensuring every related party does not put aside security and safety issues and protecting the maritime environment by pursuing profit. IMO keep trying to cooperate between the state and the shipping industry to 
improve maritime security and safety. Ensuring collaboration can be created running effectively, IMO made some of the regulations that can guarantee.

ISM Code or international safety management code adopted by IMO [20]. Starting from the preSOLAS (Safety Of Life At Sea) where ship accidents still often occur, especially passenger ships the period of air transportation is not yet advanced, with various causes of accidents such as human error, inadequate ship's construction, and equipment, not sophisticated equipment, and the absence of highly skilled crew members. The sinking of the Titanic in 1912 encouraged people in the maritime world that there is a need for regulations on safety, ship's construction, and equipment. SOLAS Convention was held in 1914 [21] for the first time, then improvements followed in 1929, 1948, and 1960. Another shipwreck occurred in 1987, Herald of Free Enterprise sparked the international maritime community through the IMO Resolution no. A.647, namely Guidelines on Management for the safe operation of ships and pollution prevention, to force every shipping company to take responsibility for ensuring maritime security and safety. Then ISM Code adopted by IMO through the SOLAS Chapter IX, Management for the safe operation of ships and entered into force on July 1, 1998. International Safety Management Code, or known by its abbreviation as The ISM Code, is an international code on Safety Management made by IMO. Pollution prevention, shipping safety, and maritime security is the goal and the guarantee for establishing the ISM Code [3].

\subsection{Data Analysis}

In qualitative methodology, the data analysis process is carried out, starting from the collection process to the research's report to be completed [12]. Analysis simultaneously to be carried out with collecting data that aims to sharpen the focus of observation and deepen the study into part of analyzing the data. Data analysis on qualitative study is descriptive, starting with grouping the data then interpreting the meaning of each sub-aspects and their relationship to one another. Then analyze all aspects to understand the relationship between each of it [22]. A phenomenon can be understood by an interaction with subjects through interviews, observations, and documentation to complete the research data. Data analysis includes tracking the activities, organizing, solving, synthesizing, finding patterns, and determining what should be reported according to the research focus on an ongoing basis.
Maritime security, first, can be analyzed by identifying a matrix about other concepts related to spatial maritime governance. Second, maritime threats are made to show interests in different politics and ideologies through a securitization framework. Third, knowing what stakeholders' interests are carrying out practical efforts with the recognition of enhancing maritime security through security practices theory. This framework can display the maritime mapping security [23], [24] in least four important conceptual dimensions for consideration: Seapower, marine safety, blue economy, and human security. These four concepts represent various challenges to maritime governance that is or is not a security integrity maritime. See Figure 2. [25] how Maritime Security Matrix will show some important threats to pay attention to because they are interconnected and will affect each other. [23], [25].

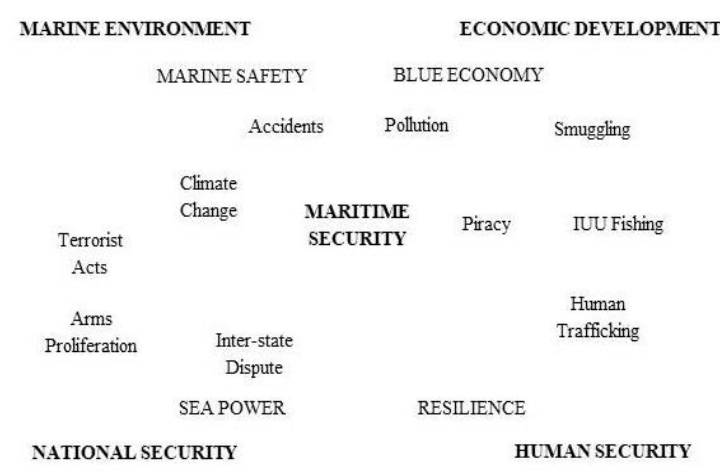

Fig. 2. Maritime Security Matrix

Table 1. Font styles for reference.

\begin{tabular}{|c|c|}
\hline Seapower & $\begin{array}{c}\text { Regarding the war of military power } \\
\text { and dimensions of maritime war } \\
\text { between countries }\end{array}$ \\
\hline Marine Safety & $\begin{array}{c}\text { Regulation of boat, sailor safety and } \\
\text { port security, terms of search and } \\
\text { rescue of maritime installations to } \\
\text { protect the marine environment }\end{array}$ \\
\hline Blue Economy & $\begin{array}{c}\text { Management of marine resources to } \\
\text { maintain the marine environment safety }\end{array}$ \\
\hline Human Security & $\begin{array}{c}\text { Regarding permanent sources and } \\
\text { livelihoods at sea, guaranteed basic } \\
\text { needs }\end{array}$ \\
\hline
\end{tabular}

\section{Results and Discussion}

\subsection{Implementation of ISM Code at KSOP II Class Tanjungpinang through international regime analysis}

Indonesia has joined the International Maritime Organization (IMO), which is the only United Nations (UN) agency that regulates safety, security, and prevention of marine pollution in the maritime industry [26]. IMO was formed in 1948 with 174 current membership countries [27]. Indonesia has also ratified the International Safety Management Code (ISM Code) in 1994 based on 
the implementation of it through the 1974 International Convention for Safety of Life at Sea (SOLAS) Chapter IX, Management for the safe operation of ships; Law no. 17 of 2008 concerning of Shipping; Regulation of the Minister of Transportation of the Republic of Indonesia Number 45 of 2012 concerning Ship Safety Management; Regulation of the Director-General of Sea Transportation Number HK. 103/2/19/DJPL/16 concerning the implementation of Ship worthiness of Ships; And the Government/Sea Transportation as Implementation \& Law Enforcement must implement/enforce the ISM Code as regulated by IMO. In the study of international relations, IMO is an International Organization that serves as a forum for its member countries, including Indonesia, regarding the maritime matters by establishing the ISM Code as an International Regime that can assist its member countries in maritime safety and security. Therefore, the ISM Code, which is a Safety Management System, with a purpose to create a shipping safety and prevent some actions that pollute the sea, was adopted by IMO and came into force on July 1, 1998, as the SOLAS Chapter IX with the ability to achieve and carry out tasks with the aim of:

1. Guaranteeing safety by preventing accidents that cause loss to human life and damaging the environment.

2. The creation of an attitude of care and responsibility for safety and actions not to pollute the waters.

They were improving efficiency and reliability in work, effectiveness, and performance of companies and ships. In the Regulation of the Minister of Transportation Number 45, the company must meet the requirements for the type and size of passenger ships, oil tanks, and cargos, such as 1). High-speed passenger ships of all sizes. 2). Chemical tankers and gas carriers with a size of 150 GT. 3). High-speed cargo ships, bulk carriers, fishing vessels, mobile offshore drilling units (MODU), and floating storage/production units (FSO/FPSO, and Off-loading Facilities), manned barge with gross tonnage size greater than or equal to GT500, then the ships can operate if they follow and meet the standards that have been set. There are also some administrative requirements or equipment for shipping safety management. The ship will be given a certificate consisting of 1). Safety Management Adjustment Document (DOC/ Document of Compliance) for the company; and 2). Safety Management Certificate (SMC / Safety Management Certificate) to ship. If you look at the purpose of the ISM Code, generally, the number of accidents will be a major concern given the ongoing implementation of the ISM Code so far. However, the number of accidents will always be debated because it is difficult to report, calculate and even normalize the number and size of accidents by type: sinking, burning, collision and run aground, injury, ship, port cargo, and others with estimated causes of accidents such as human, technical, natural negligence. The following data on ship accidents within the KSOP II Class Tanjungpinang shipping line are as follows.

Table 2. Font styles for reference.

\begin{tabular}{|c|c|c|c|c|}
\hline Year & $\begin{array}{c}\text { Ship's } \\
\text { name }\end{array}$ & Route & $\begin{array}{c}\text { Accident } \\
\text { Location }\end{array}$ & $\begin{array}{c}\text { Type of } \\
\text { accident }\end{array}$ \\
\hline 2018 & $\begin{array}{c}\text { MV } \\
\text { VOC } \\
\text { Batavia }\end{array}$ & $\begin{array}{c}\text { Anambas- } \\
\text { Tanjungpi } \\
\text { nang }\end{array}$ & $\begin{array}{c}\text { Bintan } \\
\text { Waters }\end{array}$ & Collision \\
\hline 2019 & $\begin{array}{c}\text { Wavem } \\
\text { aster 5 }\end{array}$ & $\begin{array}{c}\text { Tanjungpi } \\
\text { nang- } \\
\text { Singapore }\end{array}$ & $\begin{array}{c}\text { Galang } \\
\text { Waters, } \\
\text { Batam }\end{array}$ & $\begin{array}{c}\text { Ran } \\
\text { aground }\end{array}$ \\
\hline 2019 & $\begin{array}{c}\text { Mv } \\
\text { Indra } \\
\text { Bupala }\end{array}$ & $\begin{array}{c}\text { Singapore } \\
\text {-Lobam }\end{array}$ & $\begin{array}{c}\text { Bintan } \\
\text { Waters }\end{array}$ & $\begin{array}{c}\text { Ran } \\
\text { aground }\end{array}$ \\
\hline 2019 & $\begin{array}{c}\text { Ocean } \\
\text { Dragon } \\
6\end{array}$ & $\begin{array}{c}\text { Tanjungpi } \\
\text { nang- } \\
\text { Batam }\end{array}$ & $\begin{array}{c}\text { Air Raja } \\
\text { Waters }\end{array}$ & $\begin{array}{c}\text { Ran } \\
\text { aground }\end{array}$ \\
\hline
\end{tabular}

The accident rate also cannot be the only measurement of the effectiveness of security, but it will affect the increase and awareness of maritime security. The absence of reports of marine accidents in the NTSC shows that the implementation of shipping security still needs some improvement. Accident reporting serves to evaluate and correct everything from the ship to various regulations that are found to be inappropriate. However, the government has not overcome the problem of sea transportation regarding the port inspection system, ship worthiness, and poor shipping services management. For example, assuming you look at the number of ship activities on international routes (overseas shipping activities) at the Port of Sri Bintan Pura. In that case, there is a significant number of maritime activities in Indonesia, as follows [28].

Table 3. Number of overseas shipping activities at Tanjungpinang port

\begin{tabular}{|c|c|c|c|}
\hline \multirow{2}{*}{ Year } & \multirow{2}{*}{$\begin{array}{c}\text { Ship Visit } \\
\text { (Units) }\end{array}$} & \multicolumn{2}{|c|}{ Ship Passengers } \\
\cline { 3 - 4 } & & Arrival & Departure \\
\hline 2016 & 3,884 & 266,740 & 251,292 \\
\hline 2017 & 4,064 & 234,087 & 231,794 \\
\hline 2018 & 4,101 & 239,881 & 248,676 \\
\hline
\end{tabular}




\begin{tabular}{|c|c|c|c|}
\hline 2019 & 5,412 & 245,500 & 229,925 \\
\hline 2020 & \multicolumn{3}{|c|}{ Not operating } \\
\hline
\end{tabular}

In the contrary, the implementation of the ISM Code at the II Class KSOP Office of Tanjungpinang has several obstacles. Based on the analysis and the effectiveness of the international regime [15], the implementation of the ISM Code has not been effective. Indonesia itself has succeeded in ratifying the ISM Code (Output), but human change (Outcomes) as the making efforts to overcome issues such as the existence of shipping companies that still considering management as a formality by not putting SMK books on ships which is a form of disobedience, efforts to what can be done by the II Class KSOP Office of Tanjungpinang is in the form of discretion in dealing with accidents that have occurred in the sense That the ISM Code itself does not regulate it. Efforts to overcome the problems must return to the Director-General of Sea Transportation. So, there is no real change (impacts), nor has there been a Level of Collaboration as a form of effort in overcoming the ISM Code problem. This can be carried out to the center as the actor who signed the regime (ISM Code).

An incongruity happened, as Indonesia a member of the regime along with Singapore and Malaysia, countries that bordering the RiauTanjungpinang Islands, they consider the issue of the regime (maritime safety and security) as a problem that must be overcome. Asymmetry will be different from each other when viewed from the national interest of each country. Still, both want to overcome the problem of maintaining and even implementing safety and security in their country [29]. Therefore, each country will take actions that benefit their own country and cause harm to other countries that are also members of the regime. Cumulative Cleavages, the dominance of one actor (regime member state). So that there are stronger actors in the application of maritime safety and security, this strong country will always win while the losing country will always lose [30].

In the international regime, there are several types of problem-solving capacity. First, Institutional Setting is a rule made to regulate the behavior of actors, especially regime's member states. Second, the distribution of the power between actors in the international regime. Third, Skill and Energy is supported by the institutions/systems that have the strength or other factors with adequate skills and energy to handle the maritime safety and security issues. Skill and energy are divided into instrumental leadership and epistemic community [30]. Instrumental leadership, the existence of a dominant leadership, facilitates the formation and implementation of the regime. Epistemic community, assistance or support for the ISM Code in achieving maritime safety and security through informal organizational networks. It is also very effective in influencing the decision-making process [15]. Specifically, it shows a relationship between the level of collaboration and effectiveness as measured in behavior change. In the study of international relations, the dynamics of issues and actors have made several actors other than the state influence the international political arena, namely international organizations. Now countries as members fill and join international organizations and form a regime capable of making international organizations increasingly have a strong role in both regional and global. The international regime can influence the pattern of interests and policies of a unitary and rational country [31] and create a design of peace. But it also presents a high level of danger, where each country involved prioritizes and focuses on efforts to pursue their respective interests.

\subsection{Maritime Security analysis}

If you look at these data, it is necessary to increase and pay more attention to the problems that occur in maritime security. At the international level, said Maritime Security is a new thing [24], and the mere mention of "illegal activities" such as terrorism, illicit traffic is a threat to the peace and security of international sea [32]. This concept was created in the 1990s and has become increasingly an international attention since maritime terrorism in 2000, when modern piracy happened on the coast of Somalia, other maritime crimes have increased in recent years, such as human trafficking, problems related to the blue economy, environmental protection (maritime environmental protection), and even resources management. If maritime security has become a major concern among global security actors, the study of security and international relations has been welldistributed. However, several problems such as security at ports, illegal fishing, maritime environmental crimes, and resources management have received less attention. According to Barry Desker in "Maritime Security in Southeast Asia", the increased focus on Maritime Security Threats cannot be resisted because of the need for vigilance against the threat of terrorism. Emphasizing that the international community should not be too preoccupied with the threat of terrorism by neglecting the more important tasks and the focus given that there is an increase in the delivery of 
traffic by water, but there is no increased facilitation to ensure the smooth flow of shipping [33].

From a regional point of view, increased trade has resulted in an expansion of ship traffic (cargo and passengers), increasing the risk of collisions and accidents arising from human error and mechanical failure. Therefore, it is very important not to overlook the importance of maintaining and improving safety and navigational aids [33], including the effectiveness of the ISM Code. The Maritime Security Matrix [25] shows several important threats to pay attention to because they are interconnected, where maritime security is related to other dimensions such as human security, blue economy, and national security. IMO only focuses on Maritime Safety while Maritime Security is part of its origin, namely the state security authority. This tradition has led to a growing awareness that Maritime Safety is an integral part of Maritime Security because it has a close reciprocal relationship. Most international actors have made a Maritime Security [33], [34] plan to define maritime security by classifying several included threats in the concept. It aims to reconstruct the various threats and risks into the program of each actor.

Each actor was given an understanding of feasible and did not deserve to be protected with any actions. It shows when and how actors' interpretations of threats meet and differ significantly. This indicates that every issue of security is a top priority. But in the liberal view of institutionalism, governance and international organizations should be emphasized to make countries work together. International organizations also make the international community to play a role. People consider themselves bound by general rules in relationships and participate in cooperation. According to Robert Keohane and Joseph Nye, bound states are aware of their involvement in the international organizations based on achieving common goals. Therefore, the role of institutions will be able to suppress the chaos of international anarchy.

Table 4. Maritime Authority Framework

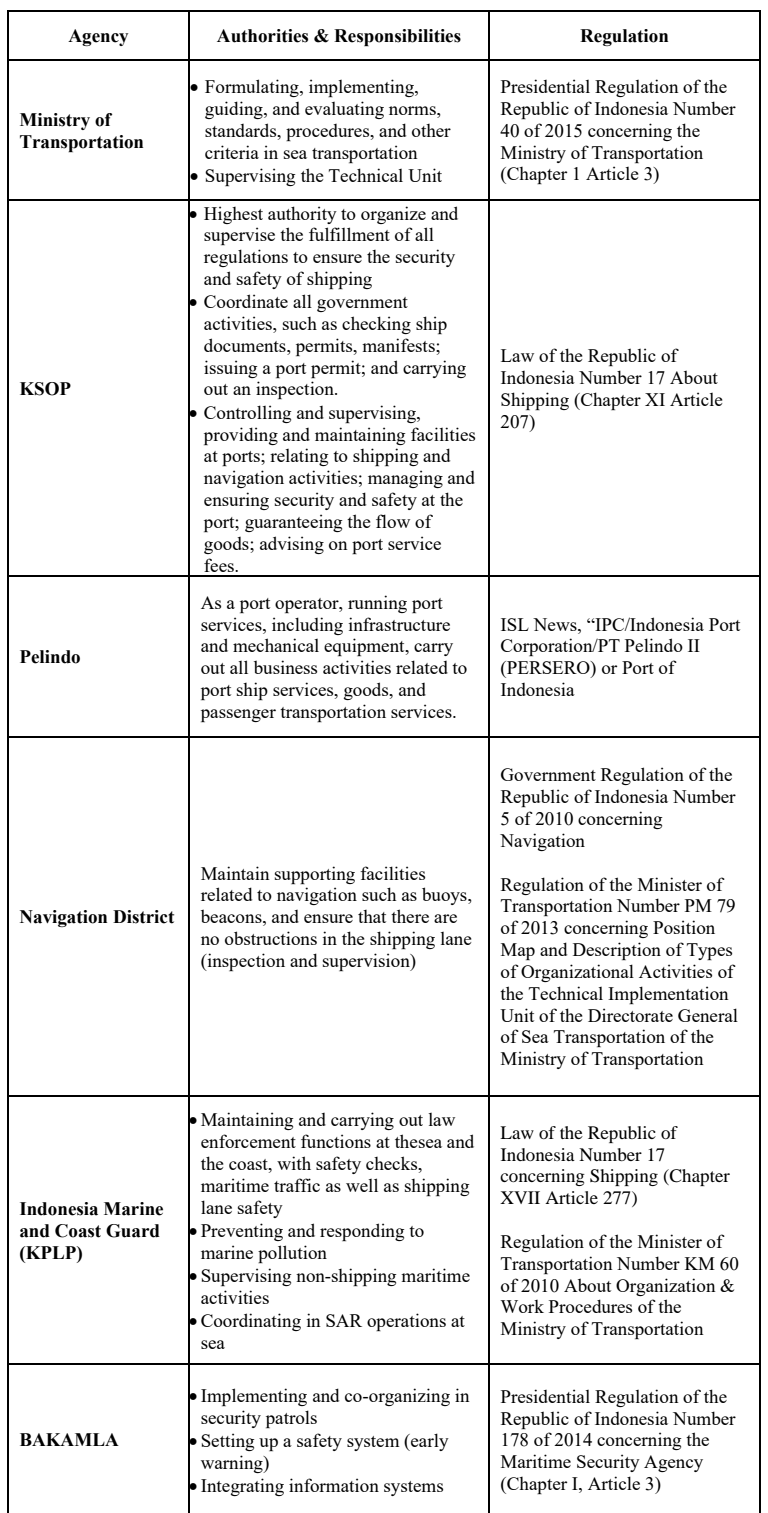

Indonesia has so many actors or stakeholders [21] enforcing regulations and intending to improve maritime security. With Indonesia's area, each actor will have a division of authority to reach each region. But some overlapping regulations and limitations hinder the implementation of maritime security. As in this study, there is a distribution of authority to actors in Tanjungpinang (KSOP II Class, I Class Navigation District, PPLP, INSA, Pelindo I, the shipping company, and the BASARNAS). That supervision and inspection can be carried out by regulators who already have certificates, and KSOP predominantly does this. However, KSOP also has limitations in making decisions in addressing the problems faced. There is no clear data on the number of shipping companies in Tanjungpinang.

\subsection{Bureaucratic Politics analysis}

In practice, the decisions of others affect the ability of each actor to make decisions. Elements such as procedures, responsibilities, time 
requirements for the task completion, questions, operations, and other intervention elements will influence the decision-making. These rights are very important in determining the results [35], [36]. Due to work pressures and costs, and high-level decisions, that person must carry out smooth and thorough operations according to procedures. This can result in a change or move towards safe working boundaries, thinking that decisions are safe and close to formal methods. Still, due to informal changes in the organization, these decisions that are believed to be safe can suddenly lead to accidents. Many organizations have too many procedures that must and are quite difficult to follow, large workloads, limited time, and variable conditions. When the decision does not match the criteria, there is a need for discretionary space. There is a need to develop safety procedures for over-knowledge of rules and reliance on practices that lead to violations.

The broad-reaching Safety Management System is rooted in the ISM Code itself, flowing down through all levels and actors. The purpose of the ISM Code is addressed by separate provisions of an agreement, namely audit and verification. Although the ISM Code facilitates local Safety Management Systems. Its emphasis on documentation, validation, and oversight makes it difficult to handle in a nonbureaucratic manner. Furthermore, it creates compulsion in management and does not increase security in the role of a local administrator, making it difficult for regulators and companies. Seafarers to fight a broad-reaching safety management system.

Existing rules and the state's dependence on institutions make the state compelled to comply with the laws, encouraging the state to create the strategies in attaining the goals specified in the institution. In international institutions, the role of the state is important in achieving common goals. However, the dominant actor remains the state, but there must be rules within the institution and influence the achievement and effectiveness of the objectives of its formation. For example, the government in Indonesia consists of work units arranged in various terminologies such as ministries, departments, directorates general, agencies, bureaus, and so on. Among them they have work units in all regions based on their authority, namely regional government officials with various terminologies [37]. In this case, the Ministry of Transportation, the Directorate General of Sea Transportation, and KSOP, the Navigation District, and PPLP based on class division must be reliable instruments in the bureaucracy.

\section{Conclusion}

In conclusion, describe the challenges of future maritime security studies as further research. In addition to traditional concerns about the study of sea power and the legal structure that regulates maritime security and order and increasing knowledge and skills and awareness of local actors and maritime stakeholders in the marine security sector. The findings may lead to a change in focus in academia in the future. They were starting to simplify administrative and auditing tasks considering that the ISM Code also benefits safety and security in certain circumstances. Simplify the rules and re-establish navigation and even administration and the roles and responsibilities of the national group of transport companies. This shows that certification alone is not enough to ensure the implementation of the ISM Code goes well, the existence of responsibilities in the agreement from top management, the effectiveness of the Safety Management System, the role of Stakeholders, human resources, materials, and facilities as well as the work environment can encourage the successful implementation of the ISM Code. Implementation of sea transportation activities requires maritime security, which seeks preventive and repressive measures to improve maritime safety to prevent threats from occurring and law violations.

\section{References}

1. Jeevan, J., Salleh, N., \& Othman, M. (2018). Thai Canal and Malacca straits: Complementing or competing for stratagem for trade development in South East Asia. Journal of Sustainable Development of Transport and Logistics, 3(2), 3448. https://doi.org/10.14254/jsdtl.2018.3-2.2.

2. Nurmandi, A. A. T. P. N. (2012). Menjaga Indoensia Dari Kepri Peluang, Tantangan, \& Proil 19 Pulau Terdepan Indonesia di Kepulauan Riau. In Badan Pengelola Perbatasan Provinsi Kepri.

3. Suwestian, M. F., Ghalib, S., \& Utomo, S. (2015). Implementasi Kebijakan Sistem Manajemen Keselamatan Pelayaran (Studi Di PT . Maritim Barito Perkasa Banjarmasin). Jurnal Bisnis Dan Pembangunan, 3(1), 1-5.L. T. De Luca, Propulsion physics (EDP Sciences, Les Ulis, 2009)

4. Law of the Republic of Indonesia Number 17 of 2008 about Shipping

5. Kadarisman, M. (2017). Kebijakan Keselamatan Dan Keamanan Maritim Dalam Menunjang Sistem Transportasi Laut. Jurnal Manajemen Transportasi Dan Logistik, 4(2), 177.

6. Puspitawati, D. (2019). Implikasi Yuridis Atas Penerapan Ism Code Dan The Legal Implications On The Implementation Of. 7(3).

7. Regulation of the Minister of Transportation of the Republic of Indonesia Number PM 78 of 2013. 
8. Regulation of the Minister of Transportation Number: KM 60 of 2010 About the Organization and Work Procedures of the Ministry of Transportation

9. Minister of Transportation Regulation Number: PM 45 of 2012 Ensuring ships are in accordance with standards, pollution prevention and issue certificates

10. Sugiyono. (2015). Metode Penelitian Pendidikan (Pendekatan Kualitatif, Kuantitatif, dan R\&D)

11. Ahyar, H., Maret, U. S., Andriani, H., Sukmana, D. J., Mada, U. G., Hardani, S.Pd., M. S., Nur Hikmatul Auliya, G. C. B., Helmina Andriani, M. S., Fardani, R. A., Ustiawaty, J., Utami, E. F., Sukmana, D. J., \& Istiqomah, R. R. (2020). Buku Metode Penelitian Kualitatif \& Kuantitatif.

12. Wahidmurni. (2017). Pemaparan Metode Penelitian Kualitatif. 12-21.

13. International Institutions And State Power: Essays In International Relations Theory by Robert $O$ Keohane. (1989).

14. Ferraro, G. (2010). Domestic Implementation of International Regimes in Developing Countries The Case of Marine Fisheries in China (Dissertation).

15. Miles, E. L., Andresen, S., Carlin, E. M., Skjærseth, J. B., Underdal, A., \& Wettestad, J. (2018). Environmental Regime Effectiveness. In Environmental Regime Effectiveness.

16. Underdal, A. (2014). Methodological Challenges and Research.

17. Keohane, R. O., \& Martin, L. L. (1995). Institutionalist Theory. International Security, 20(1), 39-51.

18. Introduction to IMO. (n.d.). Retrieved July 20, 2021, from https://www.imo.org/en/About/Pages/Default.aspx

19. McNicholas, M. (2008). MARITIME SECURITY An Introduction. In P. Chester (Ed.), Angewandte Chemie International Edition, 6(11), 951-952. ButterworthHenemann, Elsevier Inc.

20. Molland, A. F. (Ed.). (2008). The Maritime Engineering Reference Book (2008th ed., pp. 784-875). ButterworthHeinemann.

21. Mantong, Andrew; Kembara, Gilang; Dzakwan, Muhammad; Kharisma, M. (2020). Maritime Safety In Indonesia Maping The Challenges And Opportunities (S. Muhibat (Ed.); Pertama). Centre for Strategic and International Studies.

22. Firman, F. (2018). Analisis Data dalam Penelitian Kualitatif. November, 1-14.

23. Batalden, B. M., \& Sydnes, A. K. (2014). Maritime safety and the ISM code: A study of investigated casualties and incidents. WMU Journal of Maritime Affairs, 13(1), 325.

24. Bueger, C., \& Edmunds, T. (2017). Beyond seablindness: A new agenda for maritime security studies. International Affairs, 93(6), 1293-1311.

25. Bueger, C. (2015). What is maritime security? Marine Policy, 53(March), 159-164.

26. Samangun, E. (2019). Dampak Terpilihnya Kembali Indonesia Sebagai Anggota Dewan International Maritime Organization (IMO) Kategori-C Terhadap Sektor Keselamatan Maritim Di Indonesia.
27. International Maritime Orgnization Home Page. (n.d.). Retrieved July 19, 2021, from https://www.imo.org/

28. Central Agency on Statistics

29. Underdal, A. (1992). The Concept of Regime "Effectiveness." The ANNALS of the American Academy of Political and Social Science, 503(1), 122-136.

30. Boynauw, I. R. (2019). Analisis Efektivitas Kerjasama Bilateral Indonesia Dan Filipina Dalam Menangani Iuu (Illegal, Unreported, And Unregulated) Fishing Di Maluku Utara Tahun 2015-2018.

31. Prayuda, R., Harto, S., \& Gunawan, D. (2017). Politik Institusi Rezim Internasional (Konsep dan Pendekatan Analisis). Journal of Diplomacy and International Studies, 97-111.

32. Keliat, M. (2009). Keamanan Maritim dan Implikasi Kebijakannya Bagi Indonesia. Jurnal Ilmu Sosial Dan Ilmu Politik, 13(Juli), 19.

33. Kwa, C. G., \& Skogan, J. K. (2007). Maritime security in Southeast Asia. In Maritime Security in Southeast Asia.

34. United Nations. (2008). Oceans and the law of the sea. Report of the Secretary-General, UN General Assembly Document A/63/63. 26626(March).

35. Rasmussen, J. (2018). Risk Management In A Dynamic Society: A Modelling Problem. Safety Science, 27(2), 183-213.

36. Serpa, S., \& Ferreira, C. M. (2019). The Concept of Bureaucracy by Max Weber. International Journal of Social Science Studies, 7(2), 12

37. Kadir, A. (2017). STUDI PEMERINTAHAN DAERAH DAN PELAYANAN PUBLIK. In Studi Pemerintahan Daerah dan Pelayanan Publik (Pertama, pp. 153-192). CV. Dharma Persada 